\title{
Notes on Marine Algal Species from Korea
}

\author{
Pil Joon $\mathrm{KANG} \cdot \mathrm{Ki}$ Wan $\mathrm{NAM}^{\dagger}$ \\ (Pukyong National University) \\ 한국산 해조의 주해 \\ 강필준 · 남기완† \\ (부경대학교)
}

\begin{abstract}
해양 생물은 중요한 생물자원으로 인식되고 있다. 특히, 해조류 자원은 식용, 유용 유기물질 추출, 바이 오연료 생산, 탄소 흡수 등과 같은 많은 잠재적인 이용 가능성을 갖는다. 한국산 자생생물 조사의 일환으 로 Halymenia latifolia P.L. Crouan et H.M. Crouan ex Kützing, Grateloupia livida (Harvey) Yamada and Hypnea boergesenii Tanaka의 3종이 동해 연안에서 채집되었다. 본 3종에 대한 형태학 및 분류학적 주해가 본 연구에서 제시된다. 이 중에서 Halymenia latifolia는 한국산 미기록 종으로 여기서 처음으로 보고된다.
\end{abstract}

Key words : First record, Halymenia latifolia, Grateloupia livida, Hypnea boergesenii, morphology, taxonomy, Korea

\section{I . Introduction}

With the contraction of $\mathrm{CBD}$ (Convention on Biological Diversity) (1992), bioresources are currently object for active investment in the world (Moran et al., 2001). Significance of marine bioresources with high biodiversity as self-renewal sources has been emphasized, particularly in Korea which is peninsula. Of these bioresources, marine algae play an important role not only as habitat and food of marine organisms, and primary producer in marine ecosystem but also as fundamental source of a higher value-added bioindustry for production of biofuel and useful natural organic material. In addition, this resources are expected as carbon sink in CDM (Clean Development Mechanism) projects to global warming (Kang et al., 2008; Adenle et al., 2013).

Since Kang (1966), many species have been added to Korean marine algal flora (Lee and Kang, 1986, 2002). Recently, this kind of study has been vigorously carried out in Korea. It appears that about 900 species are currently recorded in the Korean marine algal flora (Boo and Ko, 2012).

In the course of the survey of indigenous species in Korea, many marine algal species were found in Korea. Of these, three marine algal species, Halymenia latifolia P.L. Crouan et H.M. Crouan ex Kützing, Grateloupia livida (Harvey) Yamada and Hypnea boergesenii Tanaka, which were collected

† Corresponding author : 051-629-5922, kwnam@pknu.ac.kr

* This work was supported by a Research Grant of Pukyong National University (2013). 
from eastern coast of Korea, were examined in details. Morphological and taxonomic notes on these species are included in the present study. Halymenia latifolia is newly recorded from Korea here.

\section{II . Materials and Methods}

Specimens for the present study were collected along the eastern coast of Korea. Taxonomic data were obtained from fresh, liquid-preserved and herbarium specimens. Liquid-preserved material was stored in a $10 \%$ solution of Formalin/seawater. For anatomical observations the material was cleared in $5-10 \% \mathrm{NaOH}$ in distilled water for 2-7 days, and then rinsed in distilled water. Blades dissected from the cleared materials were hand sectioned, transferred to a slide with a drop of distilled water, and mounted in pure glycerin. In some instances, a smearing method for microscopic examination was employed. Measurements are given as width and length. For photographs the sections were stained with $0.5-1.0 \%$ aqueous methylene blue, aniline blue or hematoxylin. For permanent slides, the glycerin was exchanged with $10-20 \%$ corn syrup.

\section{Results and Discussion}

Halymenia latifolia P.L. Crouan et H.M. Crouan ex Kützing 1866: 34, pl. 96.

Korean name: Gin-ip-bo-deul-ji-nu-a-ri nom. nov. (긴잎보들지누아리: 신칭).

Specimens examined: PKNU 0000126294, PKNU 0000126295 (Sadong: 23.iv.2013).

Habitat: Epilithic in intertidal to subtidal.

Morphology: Thalli 10-15 cm high [Fig. 1A], spatulate to lanceolate, rather narrow, without midrib, dark red to brown in color, gelatinous in texture, attached on substrate by small discoid holdfast [Fig. 1B]; stipe short; axes dichotomously divided, without proliferations, with entire margin, 400-500 $\mu \mathrm{m}$ thick; cortex six to eight cell layers thick, with three to four cell layers in outer cortex; inner cortex ellipsoidal to round in cell shape, sometimes forming dichotomous filaments, usually with stellate cells [Fig. 1D]; secondary pit-connections present in cortex; refractive ganglioid cells usually present in medulla [Fig. 1E]; medullary filaments loosely arranged, oriented transversely [Fig. 1C]; spermatangia clavate, cut off from outer cortical cell, scattered over surface of thallus [Fig. 1F]. Female and tetrasporangial plants were not collected during the present study.

Remarks: Halymenia latifolia was originally introduced from Brittany coast, France with brief description (Guiry and Guiry, 2014). Later, this species was observed in detail by several researchers (Kylin, 1930; Dawson, 1954; Abbott, 1967; Maggs and Guiry, 1982). Our specimens collected from Ulleungdo are assigned to Halymenia based on transversely oriented filaments and refractive ganglioid cells in medulla, and fit well with $H$. latifolia in gross morphology.

68 species are currently accepted in Halymenia (Guiry and Guiry, 2014). Of these, two species, Halymenia dilatata and $H$. formosa, have been recorded from Korea (Lee and Kang 2002; Lee 2008; Nam and Kang 2013). Halymenia latifolia is distinguished from those two species by branching and habit. Halymenia dilatata has elliptical to round thallus and $H$. formosa has many branches and proliferations. By contrast, Halymenia latifolia has spatulate to lanceolate thalli divided sometimes dichotomously. However, it appears that thallus of Korean Halymenia latifolia is narrower than that of European specimens of the species (Maggs and 
Guiry, 1982). This is the first record of $H$. latifolia from Korea.
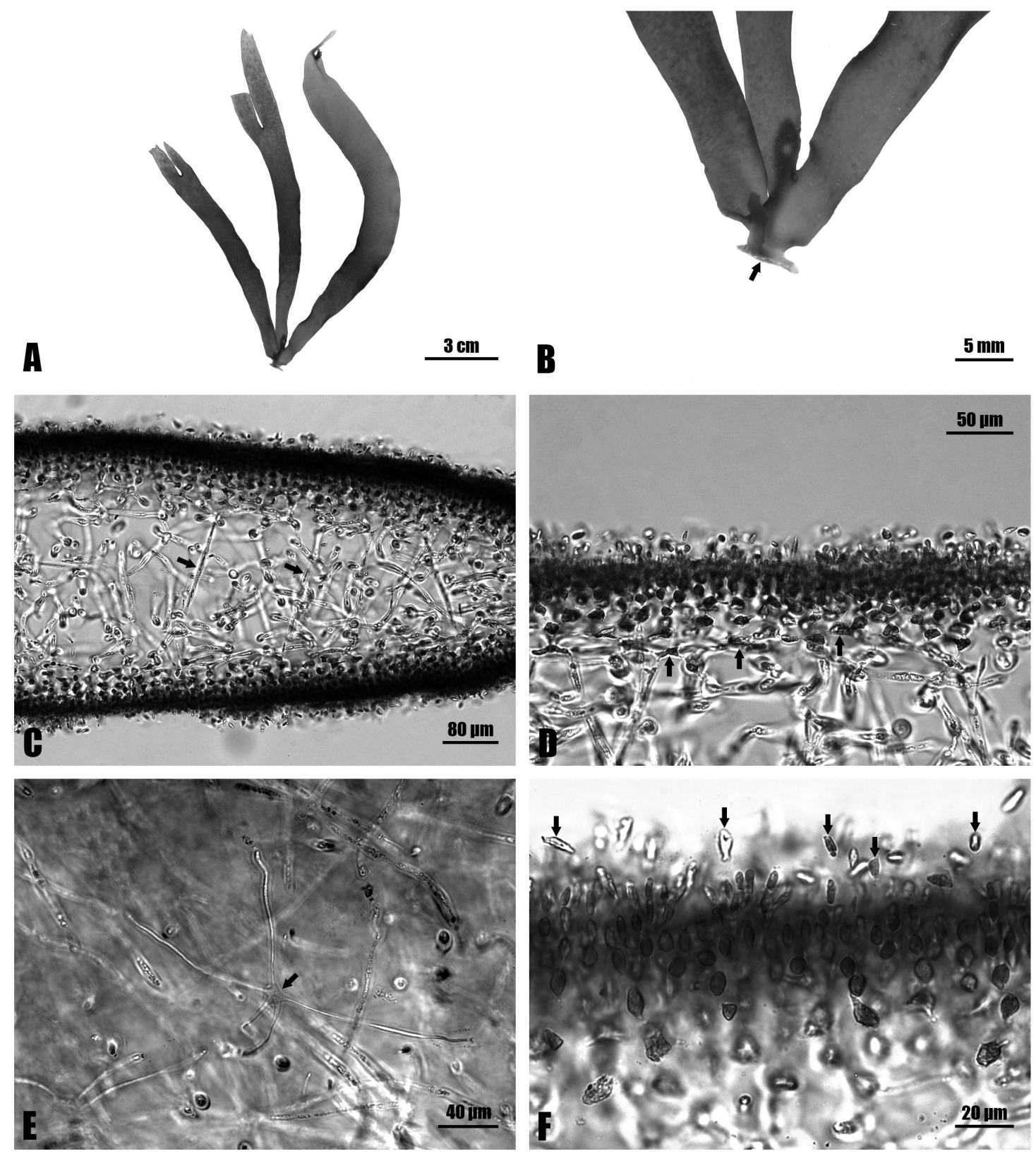

[Fig. 1] Halymenia latifolia. A, Habit of vegetative plant; B, Basal discoid holdfast (arrow); C, Loosely arranged medulla with transversely oriented filaments (arrows); D, Stellate cells (arrows) with secondary pit connections between adjacent cells in cortex; E, Refractive ganglioid cells (arrow) in medulla; F, Spermatangia (arrows) cut off from outer cortical cell. 
Grateloupia livida (Harvey) Yamada 1931: 74.

Korean name: Neolb-eun-ji-nu-a-ri (넓은지누아리).

Specimens examined: PKNU 0000126299, PKNU 0000126300 (Sadong: 23.iv.2013).

Habitat: Growing on rock near lower intertidal to subtidal.

Morphology: Thalli 10-30 $\mathrm{cm}$ high [Fig. 2A], compressed, without midrib, brown to light brown in color, cartilaginous in texture, attached on substrate by small discoid holdfast; main axes wide, 1-3 cm wide, issuing branches and proliferations on margin; branches sometimes dichotomously divided; proliferations lanceolate, short, pinnately or irregularly arranged, tapering upward, with distinct basal constriction, $1-2 \mathrm{~mm} \times 0.5-3.0 \mathrm{~cm}$ [Fig. 2B]; cortex five to eight cell layers, with two to three cell layers in outer cortex [Fig. 2C]; inner cortex cells round to ellipsoidal in cell shape, with stellate cells [Fig. 2D]; secondary pit-connections present in cortex; medullary filaments loosely entwined, without refractive cells; carpogonial branches 2-celled, conical in shape [Fig. 2E \& F]. Male and tetrasporangial plants were not during the present study.

Remarks: Grateloupia livida was originally described as Nemastoma livida Harvey (1857). There are many reports on occurrences of this species in Korea (Kang, 1966, 1968; Lee and Kang, 1971, 1986; Kim and Kim, 2000). However, most of those reports have no description of $G$. livida. According to Yoshida (1998), proliferations are observed in this species from Japan. Many proliferations are also found in our specimens from Korea. Considering the holotype specimens without proliferations (Masuda et al., 1995, fig. 21, as Nemastoma livida), it appears to be very variable in this feature.
Hypnea boergesenii Tanaka 1941: 233.

Korean name: Wang-ga-si-u-mu (왕가시우무).

Specimens examined: PKNU 0000187669, PKNU 0000187670 (Pohang: 23.vii.2013).

Habitat: Growing on rock near upper to lower intertidal.

Morphology: Thalli 5-15 cm high [Fig. 3A], terete, bright to dark red in color, cartilaginous in texture; main axes percurrent, linear, issuing branches and proliferations [Fig. 3B]; branches alternately to spirally divided; branchlets clavate or spinous, not hooked, abundant, sometimes showing adaxial bending, attenuate at apex, with basal constrictions, 1-5 mm long; lenticular thickenings always present in the wall of medullary cells [Fig. 3D]; cortex consisted of small cells, one to three cell layers thick [Fig. 3C]; medullary cells round to elliptical in transverse section; tetrasporangia restricted in ultimate branchlets, zonately divided, 15-25 $\mu \mathrm{m} \times$ 25-40 $\mu \mathrm{m}$ [Fig. 3E \& F]. Sexual plants were not during the present study.

Remarks: Occurrence in Korea of Hypnea boergesenii, which was originally described from Taiwan (Tanaka, 1941), was reported by some authors (Koh, 1990; Shin and Boo, 1994). However, morphological information is not enough to understand of Korean $H$. boergesenii. In general, medullary lenticular thickenings are considered as useful character in Hypnea (Tseng, 1984; Chiang, 1997; Xia and Wang, 1997; Geraldino et al., 2010). Unlike Shin and Boo (1994), these features are always observed in our specimens as original description (Tanaka, 1941). Hypnea boergesenii is distinguished from other Korean Hypnea species by percurrent axis, abundant branchlets densely covering axis and branches with basal constrictions including the presence of lenticular thickenings in wall of medullary cells. 

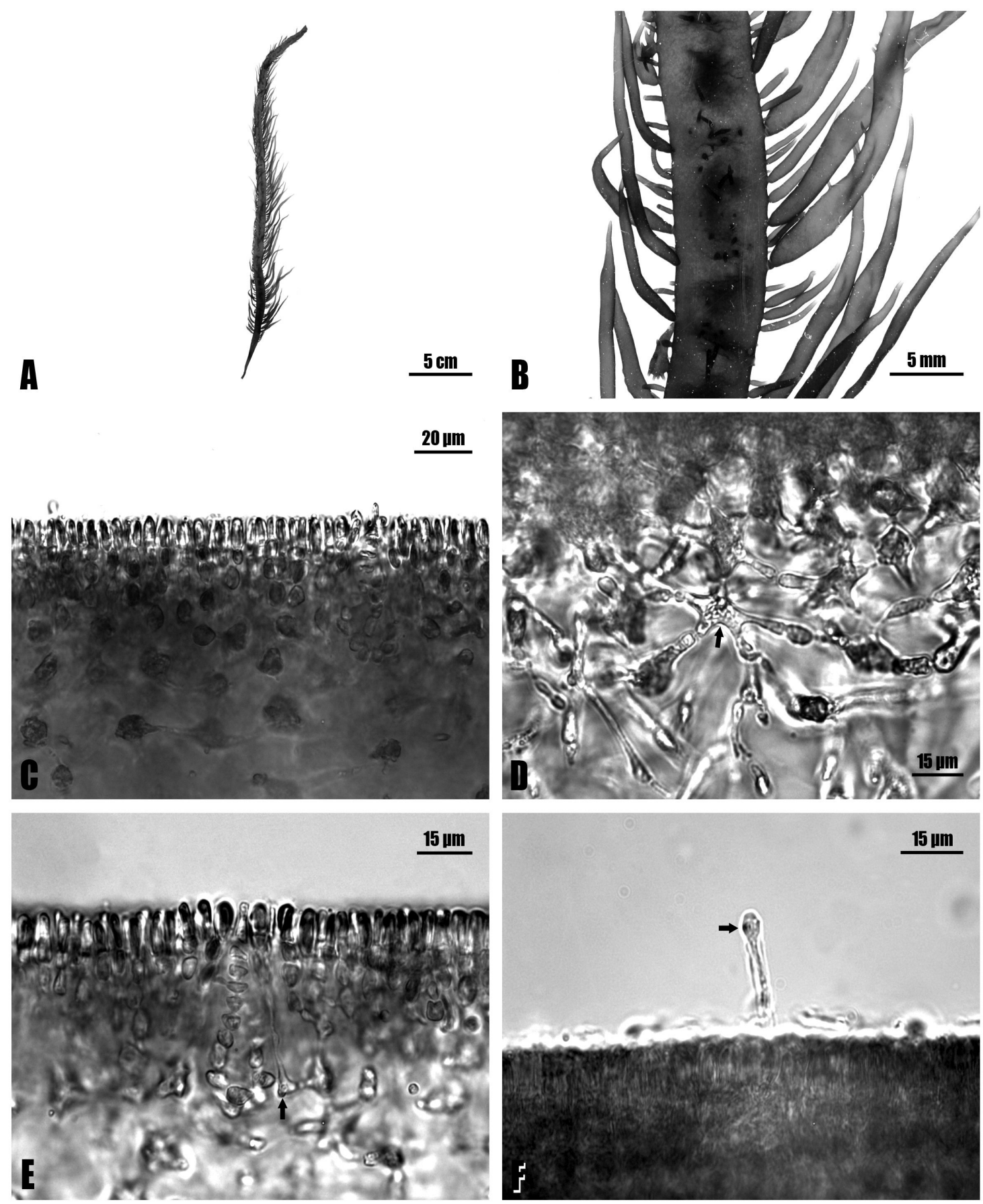

[Fig. 2] Grateloupia livida. A, Habit of vegetative plant; B, Proliferations with basal constrictions on axis; C, Cortex; D, Stellate cell (arrow) in inner cortex; E, Carpogonial branch ampulla with carpogonium (arrow); F, Tricogyne (arrow) on thallus surface 

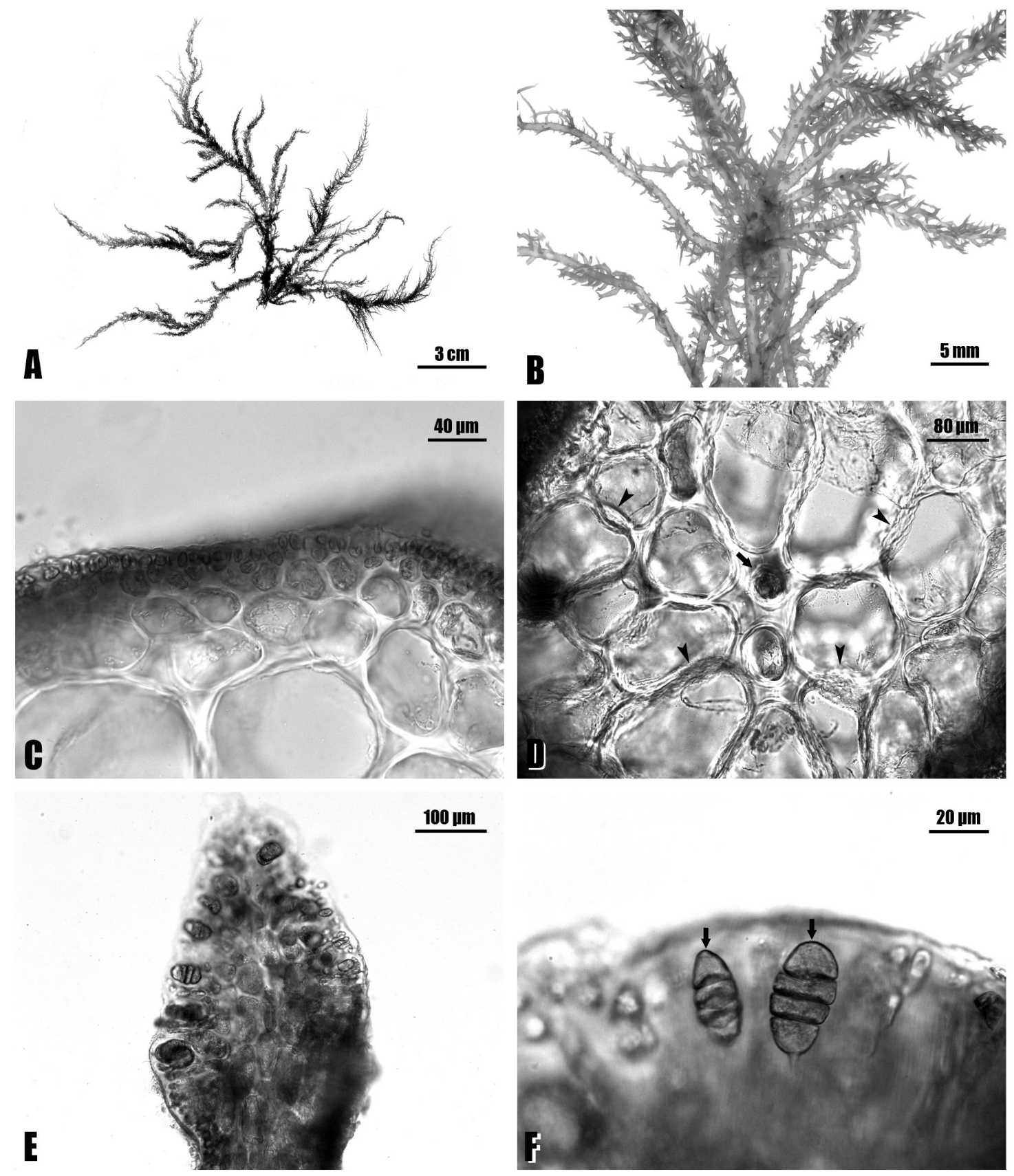

[Fig. 3] Hypnea boergesenii. A, Habit of vegetative plant; B, Details of branches with many lateral branchlets; C, Cortex of main axis; D, Medullary cells with lenticular thickenings (arrowheads) and axial cell (arrow) in transverse section of axis; E, Tetrasporangial branchlets; F, Tetrasporangia (arrows) with zonate division 


\section{Reference}

Abbott, I. A.(1967). Studies in some foliose red algae of the Pacific coast, I. Cryptonemiaceae, Journal of Phycology 3, 139 149.

Adenle, A. A. · Haslam, G. E. \& Lee, L.(2013). Global assessment of research and development for algae biofuel production and its potential role for sustainable development in developing countries, Energy Policy 61, 182 195.

Boo, S. M. \& Ko, Y. D.(2012). Marine Plants from Korea. Seoul: Marine \& Extreme Genome Research Center Program.

CBD(1992). Convention on Biological Diversity. Text and Annexes, the Interim Secretariat for the CBD Geneva Executive Centre.

Chiang, Y. M.(1997). Species of Hypnea Lamouroux (Gigartinales, Rhodophyta) from Taiwan. In: Taxonomy of Economic Seaweeds. (Abbott, I.A. Ed) Vol.6. California Sea Grant College System, La Jolla, California, 163 177.

Dawson, E. Y.(1954). Marine red algae of Pacific Mexico. Part 2. Cryptonemiales (contd.), Allan Hancock Pacific Expeditions 17, 241 398.

Geraldino, P. J. L. · Riosmena-Rodriguez, R. - Liao, L. M. \& Boo, S. M.(2010). Phylogenetic relationships within the genus Hypnea (Gigartinales, Rhodophyta), with a description of $H$. caespitosa sp. nov. Journal of Phycology 46, 336 345.

Guiry, M. D. \& Guiry, G. M.(2014). AlgaeBase. World-wide electronic publication, National University of Ireland, Galway. http://www.algaebase. org;searched on 27 January 2014.

Harvey, W. H.(1857). Algae. In: Account of the Botanical specimens. (Gray, A., ed) Narrative of the expedition of an American squadron to the China Seas and Japan, performed in the years 1852, 1853 and 1854, under the command of Commodore M.C. Perry, United States Navy, Volume II - with illustrations. (Anon. Eds), pp. 331 332, Washington: Senate of the Thirty-third Congress, Second Session, Executive Document. House of Representatives.

Kang, J. W.(1966). On the geographical distribution of marine algae in Korea, Bulletin of Pusan Fisheries College 7, 1 125.
Kang, J. W.(1968). Illustrated Encyclopedia of Fauna and Flora of Korea, Vol.8. Marine algae, Seoul: Samhwa Press.

Kang, P. J. • Kim, Y. S. \& Nam, K. W.(2008). Flora and community structure of benthic marine algae in Ilkwang Bay, Korea. Algae 23, 317 326.

Kim, M. K. \& Kim, K. T.(2000). Studies on the seaweeds in the islands of Ullungdo and Dokdo: I. Decrease of algal species compositions and changes of marine algal flora. Algae 15, 119 124.

Koh, N. P.(1990). An ecological study of resources of marine plants in Geomundo Islands, The Korean Journal of Phycology 5, 1 37.

Kützing, F. T.(1866). Tabulae phycologicae; oder, Abbildungen der Tange, Vol. XVI. Nordhausen: Gedruckt auf kosten des Verfassers (in commission bei W. Köhne).

Kylin, H.(1930). Über die Entwicklungsgeschichte der Florideen, Acta Universitatis Lundensis 26, 1-104.

Lee, I. K. \& Kang, J. W.(1986). A check list of marine algae in Korea, The Korean Journal of Phycology 1, 311 325.

Lee, K. W. \& Kang, J. W.(1971). A preliminary survey of the algal flora and community of Dongbaiksum, Pusan. Publication Marine Laboratory Pusan Fisheries College 4, 29 37.

Lee, Y. \& Kang, S. Y.(2002). A Catalogue of the Seaweeds in Korea, Jeju: Jeju National University Press.

Lee, Y.(2008). Marine Algae of Jeju, Seoul: Academy Publication.

Maggs, C. A. \& Guiry, M. D.(1982). Morphology, phenology and photoperiodism in Halymenia latifolia Kütz, (Rhodophyta) from Ireland. Botanica Marina 25, 589 599.

Masuda, M. · Kudo, T. · Kawaguchi, S. \& Guiry, M. D.(1995). Lectotypification of some marine red algae described by W. H. Harvey from Japan, Phycological Research 43, 191 202.

Moran, K. - King, S. R. \& Carlson, T. J.(2001). Biodiversity Prospecting: Lessons and Prospects, Annual Review of Anthropology 30, 505-526.

Nam, K. W. \& Kang, P. J.(2013). Algal Flora of Korea. Volume 4, Number 9. Rhodophyta: Florideophyceae: Halymeniales: Halymeniaceae, 
Tsengiaceae, Incheon: National Institute of Biological Resources.

Shin, W. G. \& Boo, S. M.(1994). A systematic study on the genus Hypnea (Gigartinales, Rhodophyta) in Korea, Korean Journal of Phycology 9, 7 20.

Tanaka, T.(1941). The genus Hypnea from Japan, Scientific Papers of the Institute of Algological Research, Faculty of Science, Hokkaido Imperial University 2, 227 250.

Tseng, C. K.(1984). Common Seaweeds of China, Beijing: Science Press.

Xia, B. M. \& Wang, Y. Q.(1997). Some species of the genus Hypnea (Gigartinales, Rhodophyta) from
China. In: Taxonomy of Economic Seaweeds, (Abbott, I. A. Ed) Vol.6. California Sea Grant College System, La Jolla, California, 193 206.

Yamada, Y.(1931). Notes on some Japanese algae II, Journal of the Faculty of Science, Hokkaido Imperial University Ser. 5. 1, 65 76.

Yoshida, T.(1998). Marine Algae of Japan, Tokyo: Uchida Rokakuho Publishing.

- 논문접수일 : 2014년 01월 14일

- 심사완료일 : 1차 - 2014년 02월 18일

- 게재확정일 : 2014년 02월 21일 